\title{
NILAI-NILAI SOSIAL BUDAYA ISLAM Upaya Merajut Kembali “Spiritualitas"Yang Hilang
}

\author{
Masturin \\ STAIN Kudus \\ masturin04_stainkudus@yahoo.co.id
}

\begin{abstract}
Abstrak
Spiritualitas Islam sebagai respon terhadap persoalan sosial-budaya kontemporer bukan saja menjadi keharusan, namun sekaligus menjadi kebutuhan dan keharusan sejarah, baik masa dulu, kini maupun pada abad mendatang. Modernitas dengan segala dampaknya telah menimbulkan kesadaran kultural berupa kerinduan orang untuk kembali pada nilai-nilai spiritual atau terjadi semacam romantisisme sejarah. Spiritualitas Islam yang dibutuhkan ke depan adalah menggabungkan antara kesalehan simbolik-individual dan kesalehan aktual-struktural. Spiritualitas Islam yang menggabungkan sikap kesalehan simbolik dan aktual tersebut harus berfungsi dalam tiga hal yaitu fungsi emansipasi, liberasi dan transendensi.
\end{abstract}

\section{Abstract}

Islamic spirituality in response to contemporary social and cultural issues not only a necessity, but also as a need and necessity of history, both past, present and in the next century. Modernity with all its cultural impact has raised awareness of the desire of people to return to the spiritual values, or a kind of historical romanticism. Islamic spirituality is needed for the future is to combine individual godliness and godliness symbolic-actual-structural. Islamic spirituality that combines symbolic and actual devotional attitude should serve the function of three things: emancipation, liberation and transcendence.

Kata Kunci: sosial, spiritualitas, modernitas. 


\section{A. Pendahuluan}

Pada dasarnya agama berasal dari manusia yang mengalami pertemuan dengan sesuatu yang supranatural. Pertemuan ini, yang dalam istilah dikenal dengan pengalaman religius, terungkap dalam berbagai bentuk pengungkapan. Joachim Wach membagi pengungkapan pengalaman religius dalam tiga bentuk:1) tindakan (action); 2) pemikiran (thought); dan 3) jama'ah (fellowship). ${ }^{1}$

Dalam sebuah karyanya Bassam Tibi, mengutip konsep Geertz, menyatakan bahwa Islam dapat dilihat sebagai model for reality dan model of reality. Sebagai model yang pertama Islam berada pada level doktrin atau ideal - normative. Ia memperlihatkan kesatuan atau monolitik. Adapun sebagai model yang kedua berarti Islam pada awal level histories - empiris dan sosoknya menjadi beragam. Pada level terakhir ini Islam menjadi sebagai sistem budaya. ${ }^{2}$

Keaneka ragaman sistem budaya Islam ini tersebar di seluruh dunia dengan segala karakrteristik lokalnya, meskipun masih dalam kesatuan bingkai atau spirit Islam. Hal ini terlihat dalam ranah kebudayaan Islam yang majemuk seperti Islam Arab, Turki, Persia, Afrika, Indo Pakistan, Melayu, Cina, dan barat. Keanekaragaman ranah budaya Islam tersebut telah berlangsung dalam sepanjang sejarah Islam sebagai refleksi adanya interaksi dan interplay antara Islam yang kosmopolit dengan budaya lokal.

Selain itu selama ini kebudayaan Islam telah berinteraksi dengan dua kebudayaan besar yaitu helenian dan barat modern. Pada saat sekarang panetrasi kebudayaan Islam dengan ide-ide modernitas telah memberikan "wacana" baru bagi kebudayaan Islam dalam segala pranatanya, termasuk di bidang sosial budaya. Tulisan ini mencoba memberikan kondisi sosial budaya Islam akibat interaksinya dengan kebudayaan barat modern. Setelah itu akan dikemukakan respon apa yang harus dilakukan umat Islam.

${ }^{1}$ Dalam M. Joseph Kitagawa. The Comparative Study of Religion, (New York: Columbia University Press, 1958), h. 64.

${ }^{2}$ Bassam Tibi, Islam and the Cultural Accomodation of Social Change, (Oxford: Westview Press, 1991), h. 8-11. 


\section{B. Modernitas: Di Antara Kemajuan dan Kenestapaan}

Baratmodernyang dimulai abad pencerahan sejakawal telah memperlihatkan sosoknya sebagai budaya yang mengandalkan subyektivitas, kritisisme dan progresifitas. Subyektivitas mengandalkan adanya kesadaran bahwa manusia merupakan "pusat realitas" dan karenanya menjadi tolok-ukur dan punya kebebasan tak terhingga. Manusia adalah pusat dan punya kebebasan tak terhingga. Manusia adalah pusat atau subyek sejarah. Budaya kritis - rasionalistik mengandaikan bahwa akal manusia punya dua fungsi yaitu sebagai sumber pengetahuan sekaligus sebagai potensi yang secara praktis mampu membebaskan manusia dari iron-cage agama yang dianggap irrasional. Adanya kesadaran subyektif dan kritisisme akan melahirkan kemajuan.

Ketiga ciri modernitas tersebut sekaligus menjadikan kebudayaan Barat modern bersifat humanistik - rasionalistik - sekularistik - materialistik. Karena itulah modernitas setidaknya dalam perspektif Weberian, dipandang sebagai proses rasionalisasi dan sekularisasi dalam konteks kebudayaan masyarakat industri. ${ }^{3}$ Ia kemudian menyejagat melalui proses globalisasi dan developmentalisasi di dunia Islam. Dengan demikian ada hubungan erat antara modernisasi dan proses globalisasi yaitu terletak pada sistem nilai pendorongnya yang sama-sama humanistik - sekularistik. Karena itu globalisasi itu tidak bebas nilai. Hal ini dapat dilihat pada watak dasarnya serperti dikemukakan Robertson yaitu adanya proses sosialisasi (societalization), individuasi, (individuation), internasionalisasi (internasionalization), dan humanisasi (humanization). ${ }^{4}$

Sosialisasi merupakan proses menjadikan masyarakat kebangsaan modern dalam satu dunia global, sedangkan individuasi merupakan proses menjadikan individu sebagai pribadipribadi modern. Internasionalisasi bermakna bahwa pada intinya globalisasi tiada lain merupakan perluasan dan pengembangan sistem nilai barat ke dalam seluruh kehidupan masyarakat dunia modern, termasuk dunia Islam. Adapun humanisasi merupakan

${ }^{3}$ B.S. Turner, Religion and Social Theory, (London: Sage, 1991), h. xviii.

${ }^{4}$ Dalam J. Beckford \& Thomas Kuhn, The Changing Face of Religion, (London: Sage, 1991), h. 11. 
proses pemanusiaan manusia menurut sudut pandang barat yang bersifat antroposentris.

Sistem nilai itu kemudian menghegemoni pada dunia Islam. Celakanya hegemonisasi budaya modernitas itu sering dirasakan sebagai sesuatu yang tidak perlu dipersoalkan bahkan dianggap sebagai keharusan sejarah. Hal ini, seperti ditegaskan Gramaci, karena apiknya tatanan hegemoni tersebut. ${ }^{5}$ Gramaci menyebutkan sebab bertahannya hegemoni antara lain karena pemanfaatan kepemimpinan moral dan intelektual, kemampuan melakukan kompromi dengan berbagai kelompok dan dilakukan bukan dengan paksaan dan kekerasan. ${ }^{6}$

Modernitas yang telah menyejagat dengan segala kemajuan ipteknya telah memberikan dampak sosial budaya di dunia Islam. dampak-dampak itu meliputi (1) munculnya reifikasi dan obyektifikasi (2) alienasi, (3) urbanisasi, (4) anomi.

Reifikasi - obyektivikasi merupakan dua konsep yang menjadi kesatuan. Reifikasi menekankan pada proses pembendaan dalam melihat sesuatu, sedangkan obyektivikasi merupakan proses peng-obyekan manusia atau menjadikan manusia sekedar obyek. Kedua konsep itu mengandaikan adanya kecenderungan untuk membendakan segala sesuatu artinya semua sikap, pemikiran dan tindakan, termasuk keberhasilan sesuatu diukur dari aspek lahiriyah dan secara kuantitatif. Selain itu manusia menjadi terperangkap dalam sistem budaya dan teknologi yang dibuatnya sendiri, sehingga manusia menjadi dependen dan tersubstitusi dalam sistem tersebut. Manusia sekedar menjadi obyek sama seperti fungsi mesin pabrik. ia tidak lagi menjadi sebagai pencipta

${ }^{5}$ Walaupun teori hegemoni Gramaci lebih difokuskan kepada konteks interaksi dan ekploitasi elite terhadap buruh, sehingga buruh tidak melakukan revolusi sosial seperti diramalkan Marx, namun teori ini relevan juga dalam melihat pola interaksi dunia barat dengan dunia Islam. Hal ini setidak-tidaknya karena sama-sama mengandung adanya dominasi sistem sosial budaya tertentu, dalam hal ini sistem barat. Selain itu karena adanya kesamaan metodologis yaitu dalam upaya mempertahankan hegemoni dilakukan begitu cantik dengan melibatkan kaum intelektual, misalnya dalam proses pembangunan yang melibatkan berbagai konseptor intelektual dalam berbagai bidang seperti ekonomi, agama dll.

${ }^{6}$ Dalam C. Jeffrey Alexander \& Steven Seidman (ed), Culture and Society Contemporary Debates, (London: Cambridge University Press, 1990), h. 47-54. 
dan pengendali sistem. pada masyarakat yang mengalami proses reifikasi - obyektivikasi akan kian mempersubur sikap sekularistik dan materialistik.

Reifikasi - obyektivikasi pada gilirannya menimbulkan kecenderungan alienasi pada masyarakat. Suatu perasaan tidak berdaya, tidak bermakna dan terpencil di tengah-tengah hangarbingar teknologi dan manusia lain. Hal ini berjalan seiring dengan terus berkembangnya sikap individualistic masyarakat. akhirnya pada dataran sosio-psikologik, alienasi ini akan memudahkan individu mengalami ketidakseimbangan kepribadian dan mempermudah munculnya tindakan maladaptasi seperti penyalahgunaan narkotika, kriminalitas dan berbagai jenis patologi sosial lainnya.

Kecenderungan ini dipercepat lagi dengan munculnya urbanisasi. Sebab urbanisasi telah meruntuhkan nilai-nilai komunalitas dalam masyarakat tradisional, sehingga kehidupan guyub yang sarat dengan hubungan sosial yang emosional secara bertahap menjadi sirna. Hubungan lebih didasarkan pertimbangan rasional, hal ini juga seiring dengan kecenderungan sikap individualistik. $^{7}$

Anomi merupakan suatu kondisi tidak sesuainya antara perubahan struktur seperti industrialisasi dan urbanisasi, dengan kondisi budaya tradisional. ${ }^{8}$ Dampak ini muncul karena, seperti dikemukakan Habermas, adanya sesuatu yang salah dalam proses modernisasi pada rasionalitas instrumen/teknologi dan mengabaikan rasionalitas yang membebaskan. Suatu rasionalitas moral dan estetik atau rasionalitas komunikatif. ${ }^{9}$ Semestinya antara kedua rasionalitas instrumen yang mendominasi dan bahkan melakukan kolonialisasi terhadap rasionalitas adalah moral dan estetik. ${ }^{10}$

Semua kecenderungan di atas yang menyebabkan Eliot

${ }^{7}$ Kuntowijoyo, Budaya dan Masyarakat, (Yogyakarta: Tiara Wacana, 1987), h. $10-11$.

${ }^{8}$ Ibid., h. 11.

${ }^{9}$ J. Habermas, Ilmu Teknologi Sebagai Ideologi, Terj. Hasan Basri, (Jakarta: LP3ES, 1990), h. 59-62.

${ }^{10} \mathrm{C}$. Jafrey Alexander \& Steven Seidman, Op.Cit.,...h. 348. 
melakukan sindiran tajam secara puitis bahwa kemajuan yang dicapai oleh masyarakat modern pada hakikatnya justru akan menggiring mereka kepada kebangkrutan, hal itu tiada lain karena mereka mengabaikan nilai-nilai ketuhanan.

Fenomena hilangnya rasionalitas moral, khususnya yang berdimensi ketuhanan, pada masyarakat modern itu bukan saja terjadi pada masyarakat Barat, tetapi terjadi juga pada masyarakat Islam. Proses sekularisasi, reifikasi-obyektivikasi, urbanisasi, alienasi dan anomi telah, sedang dan bahkan akan berlangsung dalam masyarakat Islam modern. Walaupun begitu pada setiap ranah dan varian kebudayaan Islam itu ada berbagai tingkatan perasaan kehilangan nilai-nilai ketuhanan tersebut. Begitu pula dampak-dampak modernitas yang dirasakan oleh masyarakat Islam. Hal ini tergantung kepada aspek pemahaman ummat dan watak keislamannya. Pada gilirannya akan menentukan bentuk revitalisasi atau kesadaran balik yang diberikannya.

Dengan kata lain ada perbedaan dalam mengakomodir budaya terhadap perubahan sosial yang dimunculkan modernitas oleh umat Islam. Walaupun begitu ada dua hal substantif yang menyatukan berbagai respon umat Islam tersebut yaitu (1) kesamaan kesadaran akan adanya 'ancaman' terhadap simbolsimbol keagamaan, sehingga agama perlu dirangkul (religious mindedness), (2) ancaman itu terutama pada dimensi sukma atau spiritualitas keagamaan.

\section{Tinjauan Kajian Ajaran ke-Islaman}

Paling tidak saat ini ada tiga jenis pengkajian terhadap Islam yang, dilihat kategori pelakunya, dapat dibedakan menjadi: (1) kajian oleh umat Islam pada umumnya, (2) kajian oleh orientalis, dan (3) kajian oleh ahli ilmu-ilmu sosial modern.

Umat Islam pada umumnya mengkaji Islam dari segi warisan ajaran yang mesti diamalkan. Pengkajian bertujuan memperoleh pengetahuan teknis dalam melaksanakan perintah Allah dan menghindari larangan-larangannya yang dikaji adalah pusaka Islam yang dipilah-pilah dalam ilmu-ilmu ('ulum) semisal ilmu fiqh, ilmu kalam dan ilmu hadis. Kajiannya bersifat ahistoris, dalam pengertian bahwa ilmu-ilmu itu dipelajari lepas dari 
sejarah pembentukan dan perkembangannya. Pemilihan pun dilakukan dari berbagai aliran yang ada pada ilmu yang dipelajari. Yang dipilih adalah aliran yang dianggap ortodoks oleh kelompok yang mempelajarinya Pikiran-pikiran yang dihasilkan oleh aliran heterodoks tidak masuk dalam bidang kajian. Misalnya, dalam ilmu kalam yang dipelajari adalah kalam Ahlus Sunnah wal Jama'ah, dalam ilmu fiqih mazhab Syafi'i atau mazhab empat. Mazhab i'tizal dalam kalam dan mazhab Syi'ah dalam fiqih tidak dipelajari, kecuali pada masa-masa terakhir ini. Itu pun belum banyak dilakukan orang.

Kaum orientalis mempelajari Islam sebagaimana terpresentasikan dalam teks-teks. Karena mereka tidak terlibat secara emosional dengan ajaran Islam yang mereka pelajari, mereka dapat dengan mudah memasukkan teks heterodoks dalam kajian mereka. Kritik yang dapat diajukan antara lain adalah bahwa apa yang dikaji itu sering kali tidak mewakili apa yang sebenarnya dipraktekkan oleh kaum muslimin, tetapi dianggap mewakili. Walaupun ajaran tasawuf al-Gazali dipraktekkan oleh kaum muslimin "tradisional" di Indonesia, misalnya menganggap bahwa apa yang dipraktekkan itu sama dengan apa yang terdapat dalam kitab Ihva' 'Ulumid Din adalah kurang tepat, karena dalam praktek terdapat berbagai penambahan dan pengurangan dari apa yang tertulis dalam buku itu. Jasa mereka yang besar adalah bahwa dari kajian yang mereka lakukan banyak naskah lama yang dapat diterbitkan lagi dalam bentuk yang lebih mudah dirujuk. Misalnya, mereka melakukan penyuntingan kritis atas bukubuku ilmu kalam karya Abul Hasan al-Asy'ari, al-Maturidi dan kaum Mu'tazilah. Penerbitan karya-karya seperti ini akan sangat membantu dalam pengkajian Islam.

Ilmuwan sosial modern melakukan kajian atas Islam dalam apa yang disebut kajian kawasan. Di sini yang penting bukan Islam yang terdapat dalam 'ulum atau karya-karya klasik, melainkan apa yang dipraktekkan oleh orang-orang yang hidup di kawasan-kawasan yang dianggap representasi dari dunia Islam. Tidak penting bagi mereka apakah yang dipraktekkan itu ortodoks atau tidak, yang penting adalah bahwa suatu ajaran benar-benar dipraktekkan dan menjadi acuan perilaku orang-orang yang 
mempraktekkannya. Kritik yang diajukan adalah bahwa apa yang terekam dalam kajian mereka bisa dianggap sebagai representasi ajaran Islam dan bahwa sering kali pemilihan atas kawasan yang mewakili dunia Islam didasarkan pada pandangan klasik yang hanya melihat Islam sebagai fenomena Timur Tengah.

Sehubungan dengan itu, Muhammad Arkoun mengusulkan Islamologi terapan yang dimasudkan untuk memperbaiki keadaan Islamologi dengan memasukkan dalam rencana kerjanya penyelidikan seksama mengenai interaksi antara Islam dan kehidupan sekuler. Ciri utama kajian keislaman ini adalah keterlibatan (engagement) kajian dengan persoalan-persoalan nyata yang dihadapi masyarakat-masyarakat Muslim.

Pendorong utama dari diusulkannya bentuk baru kajian Islam ini adalah kenyataan bahwa negeri-negeri yang mayoritas penduduknya beragama Islam saat ini ditandai dengan kurangnya integrasi antara sikap pemujaan masa lalu (passeiste) yang selalu mengarah kepada tuntutan ideologis akan suatu "keaslian" Islam dan keterbukaan kepada kemodernan materiil yang terputus dari kemodernan lembaga dan budaya. Islamologi terapan harus memikirkan keadaan ini dengan menggunakan semua sumber daya penyelidikan sosiologis, etnologis dan filosofis. ${ }^{11}$

Tujuan akhir dari Islamologi terapan adalah menciptakan syarat-syarat kerja pemikiran Islam yang bebas dari pantanganpantangan masa lalu dan mitologi-mitologi kuna, membebaskan dari ideologi-ideologi yang lahir kembali. Dengan demikian kajian ini harus mulai dari persoalan-persoalan aktual dan dengan cara yang membuat penanganan persoalan-persoalan itu efektif dalarn masyarakat Muslim. Dua kutub perhatian mesti dipertautkan dalam Islamologi terapan: kutub turats dan kutub kemodernan. Sesuai dengan itu, kajian ini mesti menentukan dengan tepat makna kedua istilah ini yang sebenarnya saling bergantung: definisi turats dan bentuk hubungan yang harus dikembangkan sesaai dengannya tergantung pada gagasan modernitas yang diajukan oleh pengkaji Islam. Kita tidak mungkin menjalin hubungan yang hidup dengan turats jika kita tidak menerima

${ }^{11}$ M. Arkoun, Pour une Critique de la Raison Islamique, (Paris: Maisonneuve et Larose, 1984), h. 56. 
adanya kemodernan sebagai kenyataan, dan sebaliknya, kita tidak mungkin memberikan sumbangan yang asli kepada pengolahan kemodernan, jika terus merancukan hal-hal yang historis dan yang mitologis dalam turats. ${ }^{12}$

Ini berarti bahwa kajian Islam mesti bertujuan akhir menghasilkan karya nyata dalam bentuk ajaran, tuntunan, pedoman dan semacamnya yang berguna bagi pemeluknya dalam menghadapi persoalan-persoalan kehidupan. Secara metodologis, kajian Islam terapan harus dimulai dengan memperlihatkan korelasi antara nasib kesejarahan berbagai masyarakat Muslim dan kemajuan modern di Barat. Kajian lama tentang Islam mengabaikan pengertian korelasi ini dan berpuas diri dengan ancangan positif pada sejarah Islam: merangkum berbagai perwujudan segala potensi dan sifat dasar dalam periode pertumbuhan dan puncak pembentukan Islam. ${ }^{13}$

Sikap ideologis terhadap orientalisme telah menyebabkan kaum Muslimin mengabaikan kontribusi orientalis-orientalis besar dalam pengkajian Islam, terutama dalam mengedit dan menerbitkan lagi karya-karya ulama Islam klasik. Sikap ini mesti dihentikan dan menjadi tugas pengkajian Islam terapanlah menggantikan iklim ketidakpercayaan dan saling menjelekkan dengan tuntutan suatu penelitian ilmiah yang solider. ${ }^{14}$

Pemikiran Islam, untuk sebagian besar, masih terus berdiri di atas episteme (cara manusia memahami dan memandang kenyataan) abad pertengahan dengan ciri utama:

1. kerancuan hal-hal yang mitis dan yang historis,

2. kategorisasi nilai-nilai etika dan keagamaan secara dogmatis,

3. penegasan teologis akan keunggulan penganut atas yang bukan penganut,

4. sakrafisasi bahasa,

5. kemaksuman dan kesemaknaan dari "kebenaran" yang dikomunikasikan oleh Allah, dieksplisitkan dan disampaikan oleh ulama,

6. nalar abadi trans-historic karena berakar dalam Kalam Allah,

\footnotetext{
${ }^{12}$ Ibid., h. 57.

${ }^{13}$ Ibid., h. 57.

${ }^{14}$ Ibid., h. 47-48.
} 
dibekali dengan landasan ontologis yang mengatasi keseluruhan sejarah.

Kajian Islam harus menjawab pertanyaan mengenai syaratsyarat kesahihan yang mesti dipenuhi ketika pemikiran Islam berpindah dari episteme abad pertengahan ke episteme modern. ${ }^{15}$

Fenomena keagamaan melewati ungkapan-ungkapan dan perwujudan-perwujudan yang diajukan oleh Islam dan agamaagama pada umumnya. Sejalan dengan ini, Islamologi terapan mengkaji Islam dalam dua perspektif yang saling melengkapi:

1. sebagai kegiatan ilmiah dalam pemikiran Islam, kajian ini mengganti sikap apologetik-polemik dengan sikap perbandingan,

2. sebagai kegiatan ilmiah yang barkaitan dengan pemikiran semasa, kajian ini mempelajari contoh Islam untuk memberikan sumbangan bagi antropologi agama.

Kalau dilihat kenyataan pengkajian Islam di perguruan tinggi agama Islam (PTAI) pada khususnya dan di Indonesia serta dunia Islam pada umumnya saat ini, terlihat banyak gejala yang menunjuk kepada apa yang dinyatakan Arkoun di atas. Walaupun ilmu-ilmu kemanusiaan, seperti: antropologi, sosiologi, psikologi, linguistik dan sejarah, sudah masuk dalam kurikulum, namun pemanfaatannya dalam menganalisis masalah-masalah ilmu keagamaan belum kelihatan. Kajian ilmu-ilmu keagamaan Islam yang menghasilkan kesimpulan-kesimpulan teologis atau hukum keagamaan, yakni ijtihad masih berputar pada porosnya yang berupa dalil-dalil naqli (apakah itu langsung dari al-Quran dan Hadis atau dari pendapat ulama) dan penggarapan atasnya secara teknis, dalam kegiatan yang disebut istinbath.

Nas-nas yang diperoleh dari teks-teks suci itu pun belum digarap secara seksama dengan menggunakan perlengkapan dan metode analisis baru yang dikembangkan dalam ilmu-ilmu kemanusiaan. Historisitas teks, dalam pengertian bahwa teks itu diproduksi dalam tempat dan waktu, tertentu dan karenanya tidak lepas dari cara pandang manusia di tempat dan zaman itu, tidak masuk dalam pertimbangan ulama atau sarjana Muslim

${ }^{15}$ Ibid., h. 50-51 
yang melakukan ijtihad. Teks suci adalah Firman Allah yang lepas dari kaitan kesejarahan.

Fenomena keagamaan yang ada di luar Islam, juga ditabukan dalam pengkajian Islam oleh kaum Muslimin. Kesucian Islam dikhawatirkan akan ternodai dengan memasukkan contohcontoh kehadiran iman dalam tradisi keagamaan lain. Pendorong utama pentabuan ini sudah barang tentu adalah keyakinan keagamaan yang terbentuk dalam sejarah umat Islam. Akan tetapi, hatta dalam pengkajian ilmiah pun hal ini masih bercokol dengan kuat.

Demikian pula, terasa ada keengganan untuk membangun ajaran atau tuntunan Islami yang dibangun di atas pengamatan terhadap fenomena-fenomena alam dan kemanusiaan yang ditemui manusia dalam kehidupannya sehari-hari. Masih cukup kuat keyakinan bahwa itu tidak termasuk dalam "sumber ajaran" yang absah.

\section{Upaya Merajut Spiritualitas Islam}

Sebelum melangkah lebih jauh penting dikemukakan terlebih dahulu makna spiritualitas. Dalam tulisan ini yang dimaksud dengan spiritualitas Islam adalah dimensi terdalam atau keimanan manusia pada Sang Pencipta Yang Maha Esa atau tauhid dan tuntutan implimentasinya dalam kegiatan muslim dalam kerangka merespon terhadap persoalan sosial-budaya kontemporer.

Dalam perspektif Islam, pembangunan manusia seutuhnya harus mencakup dua dimensi yaitu dimensi jasmaniyah atau materi dan rukhaniyah atau spiritual. Peradaban Islam yang anggun pada era kejayaannya dibangun diatas landasan "fikri dan zikr", dimensi akal dan nilai ketuhanan. Jika kita mengilas balik sejarah kita akan menemukan fakta bahwa, sumbangan terbesar dan sangat substansial yang diberiukan Islam dalam perkembangan peradaban manusia adalah pada dimensi spiritualitasnya dalam makna nilai-nilai tauhidiyahnya, terutama ketika Islam kontak dengan kebudayaan Helenian dan Perso-Semitik.

Islam dengan nilai-nilai tauhidiyahnya mampu mengakomodasi pengetahuan baruyang diperoleh darikebudayaan 
di luar dirinya. Hal ini tidak menjadikan kebudayaan islam jatuh miskin, sebaliknya menjadi lebih kaya. Dimensi tauhidiyah inilah yang memberikan ikatan sekaligus menjadi penyaring dan dinamisator atau seperti dikatakan Saunders bahwa peradaban Islam hanya mengambil elemen-elemen dari luar yang dianggap baik untuk mengisi kekurangannya yang tidak bertentangan dengan nilai-nilai dasarnya. ${ }^{16}$ Hal ini sekaligus mengandaikan bahwa Islam tidak bersifat pasif namun bersifat aktif dalam makna selektif-kreatif-inovatif. Sifat-sifat ini dengan mengacu pada nilai dasar (dimensi spiritualitas / nilai tauhidiyah) telah menjadikan generasi Islam terdahulu mampu membangun peradaban khas Islam yaitu peradaban yang berpilarkan fikr dan zikr, jasmaniyah dan rukhaniyahl. Dua dimensi integral dari kemanusiaan manusia. Reduksi terhadap salah satunya akan mendatangkan kemudaratan dan hal ini secara aktual telah menimbulkan nestapa manusia modern.

Upaya menghidupkan kembali spiritualitas sebenarnya telah menjadi kesadaran bukan saja di kalangan Islam. Hal ini dampak dari perkembangan denominasi dan gerakan spiritualisme di kalangan Kristiani, Yahudi dan Shinto di berbagai belahan dunia. Naisbitt \& Aburdene misalnya mencatat bahwa sejak tahun 1960-an agama utama atau kelompok arus besar agama mengalami kemunduran, namun kelompok-kelompok yang lebih menekankan pada dimensi spiritualitas terus meningkat. ${ }^{17}$ Penegasan yang sama diberikan nasr atas pengamatannya di masyarakat barat. Bahkan Naisbitt meramalkan millinium ketiga sebagai abad spiritualitas. Kesadaran ini juga muncul di kalangan kepercayaan lokal, sehingga memunculkan banyak kelompok spiritualisme-nativistik.

Dari paparan di atas dapat disimpulkan bahwa spiritualitas Islam sebagai respon terhadap persoalan sosial-budaya kontemporer bukan saja menjadi keharusan, namun sekaligus menjadi kebutuhan dan keharusan sejarah, baik masa dulu, kini maupun pada abad mendatang. Permasalahannya yang muncul kemudian

${ }^{16} \mathrm{~J} . J$. Saunders, A History of Medieval Islam, (London: Routledge and Kegan Paul, 1980), h. 194.

${ }^{17}$ Naisbitt \& Aburdene, Spiritualitas Baru: Agama dan Aspirasi Rakyat, (Yogyakarta: DianInterfidei, 1990), h. 256-260. 
adalah bagaimana format spiritualitas baru Islam ke depan.

Sejauh ini saya telah mengemukakan tentang dampak modernitas pada dataran sosial-budaya dan kondisi yang berkembang di dunia Islam. Modernitas dengan segala dampaknya telah menimbulkan kesadaran kultural berupa kerinduan orang untuk kembali pada nilai-nilai tradisiona ${ }^{18}$ atau terjadi semacam romantisisme sejarah. Di masyarakat Islam bentuk kesadaran ini sering, menjadi tidak proporsional. Banyaknya kelompok yang hanya berorientasi kepada kepuasan batin (esoterisme) dan gerakan spiritualisme yang ekslusif menunjukkan hal ini, padahal Islam mengajarkan agar dalam membangun manusia harus memperhatikan dimensi jasmani dan rukhani.

Berdasarkan kecenderungan di atas, maka ada beberapa hal yang penting dicatat dalam rangka merajut spiritualitas baru Islam ke depan.

Pertama, kemampuan mengekspresikan kesadaran balik dalam bidang sosial budaya sangat terkait dengan kemampuan memformat spiritualitas Islam yang proportional. Oleh karena itu persoalannya bukan sekedar harus kembali kepada warisan lama seperti terkait, walaupun bukan berarti harus menafikannya sama sekali terutama pada aspek nilai-nilai komunalitasnya. Di sisi lain kita tidak mungkin mengabaikan faktor-faktor yang datang dari luar akibat interaksi Islam dengan budaya Barat. Karena itu wajar saja kalau umat Islam melakukan akomodasi budaya. Justru dengan adanya kemampuan melakukan akomodasi itulah yang menyebabkan berbagai elemen kebudayaan Islam seperti hukum, pendidikan dan bahasa memiliki resistensi dan terus hidup sepanjang sejarahnya. ${ }^{19}$

Selain itu kita harus mengambil hikmah dari apa yang dilakukan denominasi dan spiritualisme Kristiani ketika dihadapkan kepada 'boom' modernitas. Banyak diantara mereka yang pada akhirnya tidak punya nilai keagamaan karena terlalu akomodatif atau menjadi bisa karena menjadi sangat ekslusif. Slob misalnya memberikan tiga model spiritualitas baru di

\footnotetext{
${ }^{18}$ Kuntowijoyo, Budaya dan .... h. 95.

${ }^{19}$ Bassam Tibi, Islam and..., h. 57-102.
} 
kalangan Kristiani-Barat, khususnya Eropa: (1) Spiritualitas yang berorientasi pada kemanusiaan (rasional-humanis) yang justru cenderung lepas dari semangat keagamaannya; (2) Spiritualitasortodok-ekslusif yang cenderung mengasingkan diri dari dunia; (3) Spiritualitas reformis, yang mencoba melakukan penilaian kritis terhadap simbol-simbol keagamaan lama, sekaligus memberikan pemaknaan baru doktrin terutama dalam merespon persoalan kontemporer seperti etika sosial, etika politik. Model ketiga merupakan model yang cukup moderat. ${ }^{20}$

Kedua, penumbuhkembangan spiritualitas baru Islam mengandaikan juga upaya menghidupkan kembali elan profetik kenabian. Para pembawa agama muncul dalam situasi masyarakat yang mengalami degradasi spiritual, kemudian mereka memberikan pesan secara radikal dan revolusioner agar manusia menjadi makhluk yang 'baik', 'merdeka' dan 'membebaskan' manusia dari berhala (materi). Hal ini telah ditunjukkan juga oleh Nabi Muhammad, Ahmad Talib yang dikutib Earle H. Waugh misalnya menggambarkan Nabi sebagai pemimpin yang sangat revolusioner dan radikal pada jamannya. Hal ini terbukti dari kemampuannya melakukan peran pemerdekaan manusia secara radikal dari kungkungan struktur dan budaya yang sangat humanismaterialis ke struktur dan budaya tauhidiah, dari paradigma kemanusiaan ke paradigma tauhidiyah. Begitu pula perannya dalam memberdayakan kaum lemah dari elite Quraisy. Semua dilakukan dalam konteks dakwah amar ma'ruf nahi mungkar yaitu melakukan kritik (nahi mungkar) kemudian memberi solusi (amar ma'ruf) yang dilakukan secara dinamis dan menyeluruh dalam waktu relatif singkat. ${ }^{21}$

Ketiga, Spiritualitas baru Islam itu juga selayaknya memperhatikan dua aspekyaitu memberi perhatian kepada kualitas spiritual diri (personal concern) dan sekaligus punya komitmen dalam persoalan masyarakatnya (communal commitement). Dengan demikian spiritualitas Islam yang dibutuhkan ke depan adalah, meminjam istilah Kuntowijoyo dan Efendi sebagai sikap

${ }^{20}$ Dalam Interfidei, Spiritualitas Baru..., h. 76-78.

${ }^{21}$ Richard Martin, Approaches to Islam in Religious Studies, (Arizona: The University of Arizona Press, 1985), h. 55-56. 
yang menggabungkan antara kesalehan simbolik-individual dan kesalehan aktual-struktural.

Kesalehan simbolik hanya berorientasi kepada peningkatan spiritual diri, mencari kepuasan batin tanpa ada komitmen moral dan tanggung jawab sosial serta solidaritas kemanusiaan. Sebaliknya kesalehan aktual memberi dorongan bagi individu atau kelompok untuk memberi respon atas persoalan kontemporer masyarakatnya secara radikal dan progresif.

Spiritualitas Islam yang menggabungkan sikap kesalehan simbolik dan aktual tersebut harus berfungsi dalam tiga hal yaitu fungsi emansipasi, liberasi dan transendensi. Fungsi emansipasi berkaitan dengan upaya mengangkat kembali martabat manusia agar sesuai dengan fitrahnya yang terdiri dari dimensi jasmani dan rukhani. Fungsi liberasi mengandaikan bahwa spiritualitas Islam harus mampu membebaskan manusia dari belenggu struktur. Spiritualitas Islam yang berwatak emansipasi dan liberasi tersebut harus diacukan kepada fungsi ketiga yaitu nilai-nilai tauhidiyah. Di sinilah inti pembeda Islam dengan spiritualitas yang lain, baik spiritualitas nativistik maupun spiritualitas humanistik.

\section{E. Model Praksis Spiritualisme Islam}

Setelah dikemukakan mengenai karakteristik spiritualisme Islam, maka uraian berikut dibicarakan pada dataran institusi gerakan spiritualisme Islam. Model praksis ini hanyalah sebuah tawaran. Model itu harus memiliki ciri sebagai berikut :

1. jama'ah yang guyub;

2. bersifat inklusif dan non-sektarian;

3. walaupun begitu tidak kehilangan progresifitas, radikal dan militansinya dalam melakukan kegiatan sosial-budaya dalam makna yang umum;

4. berorientasi kesalehan simbolik dan aktual;

Jama'ah yang guyub. Sifat ini sebagai respon terhadap dampak urbanisasi yang telah, sedang dan akan berlangsung. Dalam komunitas kecil ini dikembangkan sifat-sifat keguyuban seperti solidaritas antar anggota dan pimpinan dan hubungan emosional harus dikembangkan, sehingga gerakan spiritualisme mampu berfungsi sebagai wadah santuari (tempat berlindung yang 
nyaman) bagi individu-individu yang teralienasi dan mengalami maladaptasi akibat perubahan sosial budaya yang cepat, terutama pada masyarakat yang sedang berada dalam tahapan transisi.

Sifat komunitas seperti ini sudah terbukti cukup efektif dalam menarik anggota masyarakat yang berada di tengah-tengah kekehidupan yang individualistik-rasionalistik. Dalam sejarah masyarakat Barat sendiri kita dapat menemukan perkembangan kelompok-kelompok guyub yang sangat berkembang ketika awalawal revolusi industri. Thompoon menemukan fakta kelompokkelompok persaudaraan (friendly societies) setiap tahunnya terus bertambah di daerah Newcastle. Mereka memiliki kebudayaan kolektif yang menekankan cita kebersamaan, tolong-menolong dan disiplin diri. Ketika terjadi transformasi kebudayaan, kolektif di kalangan kelas pekerja, tidak urung kemudian melahirkan gerakan radikal dan militan dari kelas pekerja, setelah sebelumnya diberi nuansa nilai-nilai agama dan ide-ide sosialisme. ${ }^{22}$

Di belahan Amerika kita bisa mengambil contoh kasus 'gang' dari daerah ghettos komunitas kulit hitam. Komunitas 'gang' dengan kebudayaan marginalnya (kekerasan, kekumuhan, kriminalitas, dsb) setelah diberi ruh Islam menjadi kelompokkelompok guyub yang memiliki solidaritas tinggi. Farrakhan memberi identitas sebagai prajurit Tuhan (the army of Allah) yang beralih peran sebagai pengaman lingkungannya. ${ }^{23}$

Selain itu hubungan antara pemimpin dan anggota jangan sampai bersifat hubungan dominasi-mutlak dari pemimpin, sehingga menafikan sama sekali daya kritisisme anggota dan pada gilirannya mempersubur sikap taklid di kalangan ummat. Pemimpin hanya berfungsi sebagai pembimbing, katalisator dan dinamisator kelompok.

Inklusifitas. Sifat guyub, terutama dengan berkembangnya solidaritas yang tinggi harus dijaga jangan sampai kelompok itu menjadi eksklusif, ekstrem dan fanatik yang cenderung mencela kelompok lain di luar dirinya. Sebaliknya komunitas itu harus

${ }^{22}$ Dalam Jeffrey C. Alexander \& Steven Seidman (ed), Culture and Society..., h. 173-182.

${ }^{23}$ Lebih lanjut lihat Kepel G, Allah in the West, (California: Stanford University Press, 1997), h. 49-54. 
bersifat terbuka dan non-sektarian. Secara keanggotaan harus terbuka bagi setiap orang tanpa pandang golongan, mazhab, strata dan aliran. Hubungan dengan dunia luar tetap harus dilakukan sebagaimana biasa.

Progresifitas. Adanya sifat inklusifitas tersebut tidak berarti harus menafikan sifat progresifitas, radikalisme dan militan dalam kerangka melakukan amar ma'ruf nahi mungkar di tengah kehidupan masyarakat.

Kesalehan simbolik-aktual. Lebih dari ketiga ciri tersebut, maka sudah barang tentu spiritualisme itu harus berorientasi kepada peningkatan kualitas spiritual diri yang kemudian terefleksi kepada berkembangnya komitmen sosial yaitu ikut berperan serta dalam mengatasi persoalan-persoalan kontemporer dalam masyarakatnya, misalnya dalam persoalan lingkungan hidup, hakhak asasi manusia, pendidikan, dan kemiskinan.

Model spiritualisme ini tentu berbeda dengan kelompok sempalan (splinter groups) yang cenderung bersifat eksklusif dan atau ekstrem, sehingga menjadi sangat tidak ramah terhadap adanya perbedaan pendapat dan cenderung melakukan vonis teologis. Model ini juga akan berbeda dengan gerakan terikat yang lebih berorientasi kepada dimensi esoterik atau kesalehan simbolik, sehingga sulit mengharapkan berkembangnya komitmen sosial. Memang ada beberapa tarikat yang terlibat dalam aktivitas ekonomi ataupun politik, namun hal itu tidak lebih sebagai perkecualian dan bukan watak dasar dari terikat itu sendiri.

\section{F. Penutup}

Ungkapan teoritis yang paling awal dari pengalaman religius terdapat dalam mitos, setelah melalui rehabilitasi yang dilakukan oleh para peneliti dari berbagai bidang pengetahuan kemanusiaan, diketahui tidak hanya berisi omong kosong, melainkan menunjuk kepada suatu realitas.

Pengungkapan kedua terdapat dalam doktrin. Doktrin mempunyai tiga fungsi yang berbeda:(1) pelukisan dan perumusan keimanan, (2) pengaturan kehidupan secara normatif dalam peribadatan dan pelayanan, dan (3) pembelaan keimanan dan pendefinisian hubungan iman dengan pengetahuan lain. Dengan 
demikian doktrin mengikat dan berani hanya bagi jamaah, tidak bagi yang di luarnya.

Pengungkapan yang ketiga terdapat dalam dogma. Kalau doktrin masih membuka kemungkinan untuk berbagi varian atau pilihan, dalam dogma keputusan sudah dilakukan dari antara pilihan yang tersedia.

Bagi orang yang bergulat dengan persoalan pengkajian Islam, ada dua persoalan besaryang harus dilewatinya:(1) anggapan yang keliru bahwa pusaka islam adalah sesuatu yang sakral dan dihasilkan oleh ulama-ulama atau tokoh-tokoh yang jauh dari kesalahan, sementara ia sendiri merasa kecil sehingga tidak pada tempatnya mengusik pusaka itu, (2) terlalu banyaknya ragam dalam pusaka itu, sementara tuntunan ideologis telah menentukan jenis dan bagian mana yang harus diikuti. Ini menyebabkan sikap obyektif tidak dapat diambil dengan konsisten. [ ]

\section{Daftar Pustaka}

C. Jeffrey Alexander \& Steven Seidman (ed), Culture and Society Contemporary Debates, London: Cambridge University Press, 1990.

M Arkoun, Pour une Critique de la Raison Islamique, Paris: Maisonneuve et Larose, 1984.

J. Beckford \& Thomas Kuhn, The Changing Face of Religion, London: Sage, 1991.

Jurgen Habermas, Ilmu Teknologi Sebagai Ideologi, Terj. Hasan Basri, Jakarta: LP3ES, 1990.

G Kepel Allah in the West, California: Stanford University Press, 1997.

M. Joseph Kitagawa, The Comparative Study of Religion, New York: Columbia University Press, 1958.

Kuntowijoyo, Budaya dan Masyarakat, Yogyakarta: Tiara Wacana, 1987.

Richard Martin, Approaches to Islam in Religious Studies, Arizona: The University of Arizona Press, 1985.

John Naisbitt \& Aburdene, Spiritualitas Baru: Agama dan Aspirasi Rakyat, Yogyakarta: DianInterfidei, 1990. 
Nilai-Nilai Sosial Budaya Islam

J.J. Saunders, A History of Medieval Islam, London: Routledge and Kegan Paul, 1980.

Bassam Tibi, Islam and the Cultural Accomodation of Social Change, Oxford: Westview Press, 1991.

B.S Turner, Religion and Social Theory, London: Sage, 1991. 
Masturin

halaman ini bukan sengaja dikosongkan 